\title{
Toll-Like Receptor 4
}

National Cancer Institute

\section{Source}

National Cancer Institute. Toll-Like Receptor 4. NCI Thesaurus. Code C30105.

Toll-like receptor 4 ( $839 \mathrm{aa}, \sim 96 \mathrm{kDa}$ ) is encoded by the human TLR4 gene. This protein is involved in regulation of both fatty acid-induced inflammation and the innate immune response following bacterial lipopolysaccharide binding. 